\title{
MEDIATION INSTITUTION: EXPERIENCES FROM COUNTRIES ACROSS THE WORLD
}

\author{
Mykhailo Pitiulych ${ }^{1}$, Iryna Nakonechna ${ }^{2}$
}

\begin{abstract}
The aim of the article is to study the process of implementation of the institute of mediation in Ukraine and across the world. The subject of the study is mediation institution, analysed from scientific perspectives and on the basis of provisions of foreign and Ukrainian legislation. Methodology. The study is based on general scientific and special-scientific methods and techniques of scientific knowledge. The logical semantic method enabled to determine the content of the concepts of "mediation" and "labour dispute". The comparative legal method enabled to compare the doctrinal approaches to this issue. The same method enabled to analyse the legislation on the subject matter in the US and leading European countries. The normative dogmatic method enabled to interpret the content of legal regulations of domestic and foreign legislation that regulate the issue of mediation. The systemstructural method enabled to identify the main differences of mediation from other ways of economic dispute resolution. Methods of analysis and synthesis enabled to identify the main purpose of mediation and the main task of a mediator, as well as the key advantages of this institution. The method of legal modelling enabled to develop proposals regarding this institution introduction in Ukrainian legislation. Practical implications. Studies on mediation institution in the US and leading European countries helped to develop recommendations for this institution introduction in Ukrainian legislation, as well as to identify issues requiring further consideration and research. Relevance/originality. The concepts of "mediation" and "greenmail" are defined. The main purpose of mediation and the main task of a mediator, as well as the key advantages of this institution, are identified. In Ukraine, in comparison with other countries, the indecisiveness and inconsistency of the actions of the domestic legislator are stated as the key problem of mediation institution. It is underlined that nowadays-Ukrainian society is ready for this institution's introduction because mediation is the alternative way of dispute resolution, which enables to solve a number of social and economic problems.
\end{abstract}

Key words: foreign experience, mediation, dispute resolution, legislation, legal regulation.

JEL Classification: J52, K34, L43

\section{Introduction}

Any socially oriented democratic state of the world is obliged to create conditions, under which each person will feel protected in all activities. In the context of the global economic crisis, constant fluctuations in the economy and the growth of unemployment, the issue of labour rights protection of workers is particularly acute. International labour law provides a number of labour guarantees, among which one of the keys is the ability to protect their rights in accordance with the law. However, the high corruption of courts and a significant delay in labour dispute resolution affects negatively the quality of labour rights protection by this body of state power. Therefore, new institutes in the area of labour occur, among which mediation plays an important role all over the world. Indeed, this method allows for a more efficient and qualitative labour dispute resolution. However, despite all the progressiveness, a number of problematic issues related to mediation introduction not only in Ukraine but also all over the world. Meanwhile, it should be noted that in some states, the institution of mediation functions effectively.

Some specific issues regarding mediation introduction in Ukraine were considered in the works of: R. L. Hordiienko, M. Ya. Polishchuk, P. S. Prybutko, R. V. Mykhailenko, L. M. Dubchak, A. P. Huskova, D.V.Matkina,P.A.Bushchenko,A.M.Sliusar,N.M.Shvets, V. V. Zhernakov, S. A. Podoliak, T. O. Podkovenko, O. O. Sosiura, D. A. Kratiuk, and many others. However, despite a large number of scientific researches, there is no comprehensive study on the comparative legal analysis of mediation institution in Ukraine and in the countries across the world in legal literature. Therefore, the aim of the article is to study the process of implementation of the institute of mediation in Ukraine and across the world.

\footnotetext{
Corresponding author:

${ }^{1}$ Uhhorod National University, Ukraine.

E-mail: zarybey@bigmir.net

${ }^{2}$ National Academy of Internal Affairs of Ukraine, Ukraine.
} 


\section{Presentation of the main material}

Primarily, it should be determined what mediation institution is in general? The term "mediation" comes from the Latin for "intermediary," mediatio; the same meaning has the word in English, in French (médiation). In social psychology, scientists consider mediation as a specific form of the resolution of disputes, conflicts, reconciliation of interests (Materialy kursu pidhotovky mediatoriv iz kola posadovtsiv; Hordiienko). Both domestic and foreign scientists have tried to define the essence of the concept of "mediation." For example, A. Rau, T. Sherman, and S. Peppet, exploring alternative dispute resolution, define mediation as a process, in which the parties, with the assistance of a third party neutral, systematically make efforts to find out their common and different views, explore the possibilities of alternative dispute resolution and seek compromises to reach an agreement on resolving their own dispute (Rau, Sherman, Peppet, 2002; Polishchuk, 2014). $\mathrm{Ch}$. Moore argues that mediation is often an interference in a negotiation or conflict of a third party who is not authorized to decide on dispute resolution but helps the parties to resolve the dispute voluntarily. Moreover, the mediation procedure should also contribute to restoring trust and mutual respect between the parties (Moore, 2003). Ch. Besemer defined mediation as a technology for solving the conflict with the participation of a neutral third party. Most define mediation as a specific conflict resolution approach, in which a neutral third party provides a structured process to assist conflict parties to come to a mutually acceptable resolution to controversial issues (Materialy kursu pidhotovky mediatoriv iz kola posadovtsiv; Hordiienko).

Ukrainian researchers have also considered the definition of the essence of the specified term. In particular, H. V. Yeromenko argues that mediation is a process of negotiation to resolve a controversial issue involving a neutral third party, a mediator, who conducts this negotiation process, hears the arguments of the parties on the substance of the dispute and actively helps them understand their own interests, evaluate the possibility of compromises and come to satisfactory decision on their own. To be precise, the author states that mediation is one of the so-called alternative (extrajudicial) dispute resolution, the effectiveness of which is particularly high in all countries where this institution is introduced (Yeromenko).

In Conflict Resolution Studies, according to P. S. Prybutko, P. V. Mykhailenko and L. M. Dubchak, "mediation" (from Latin mediation for "intermediation") is private and confidential use of mediators to resolve a conflict situation. It enables to avoid time-consuming litigation and unpredictable extra costs. The authors emphasize that mediation is the process of conflict settlement between two disputing parties with the participation of the third neutral party. As an alternative to litigation and other forceful procedures, mediation has a number of advantages, the most important of which is conflict resolution through the parties' decision made voluntary and equitably, which equally satisfies the parties concerned (Prybutko, Mykhailenko, Dubchak et al., 2010).

T. I. Shynkar understands mediation as an alternative to the judicial procedure form of pre-trial or out-ofcourt or extra-judicial dispute resolution and conflict settlement, which is voluntarily chosen by parties concerned (or appointed by the authorized body), with a view to reaching an agreement between them, and which structured procedure requires the presence of a third party (impartial and neutral mediator); mutually agreeable for the parties to a dispute or conflict, not authorized to make own decisions for any of the disputing parties, but intended to provide professional, comprehensive (multi-sided) assistance to a fair resolution/settlement of a conflict/dispute and through mediation bringing the disputing parties to a stable and constructive dialogue, which in the end leads to a compromise, stable, and mutually appropriate to the parties agreement to achieve preventing or reducing the conflict, eliminating its determinants, improving its resolution, reducing costs of resolving the conflict/ dispute and/or refusing to litigate a conflict/dispute, terminating proceedings already begun and/or reducing total claims (Shynkar, 2017).

A. P. Guskova and D. V. Matkina argue that mediation is an out-of-court dispute settlement between subjects with the participation of a disinterested party; one of the informal ways of conflict resolution; a process in which the parties meet together with the elected, impartial, neutral mediator (arbitrator) who assists with negotiation to develop a mutually acceptable, viable decision under the existing conflicting interests between them (Guskova, Matkina, 2009). According to $S$. F. Demchenko, the main differences between traditional litigation and mediation are that the judge hears the parties and, based on the relevant articles of the law, makes a decision. On the contrary, the task of the mediator is much more complicated: to assist the conflicting parties with own way to resolve a controversial issue. Therefore, the mediator must have additional specific knowledge. Know how to organize the process of conflict resolution in such a way that its parties would be involved in the process of voluntary creative search for such a solution to their dispute that would satisfy both sides and open up new opportunities for their further interaction (Demchenko, 2009).

It is worth agreeing with M. M. Kuzmina, that the main objective of mediation is an orientation towards reaching an agreement, a consensus, a joint decision that will satisfy both parties of the conflict. The main difference between mediation and other methods of economic dispute resolution is that it does not focus on finding and proving the rightness of a particular party. 
The main task of the mediator is to concentrate efforts on strengthening the ability of the parties to mediation, on parties' recognizing and accepting each other with all differences in views. A mediator is a person whose task is to assist the parties to achieve reconciliation in the dispute. The mediator has no authority to make decisions, and his/her role and importance in the mediation process are determined by the following three positions: 1) providing feedback to the disputing parties so that they can understand the prospects for dispute resolution and find out the main needs and interests of each other in the present dispute; 2) rationalization of parties' negotiation; 3) encouraging the disputing parties to negotiate on the principle approach and find solutions that are generally in line with their main interests, and in individual cases and at the request of the parties, introduction of significant proposals aimed at stimulating, directing the parties to reach agreement (Kuzmina, 2008).

To sum up, the above arguments prove that mediation, as a way of dispute (conflict) resolution, can be used in many areas of public life, depending on specifics and peculiarities acquired. Since in this work, mediation is considered as a mechanism for the resolution of a labour dispute, the latter should be determined. Labour disputes are disagreements, unresolved in direct negotiations, between the worker (the staff) and the employer regarding the application of labour law regulations, as well as the establishment of new or changes in existing working conditions. The moment of labour dispute occurrence is the claim to the appropriate body examining labour disputes (Ortynskyi, Hryshchuk, Matska, 2008).

In the Labour Law Study, according to P. A. Bushchenko, A. M. Sliusar and N. M. Shvets, labour disputes are understood as disagreements, unresolved by direct negotiations, between the employee (or his/her authorized representative) and the employer (or his/her authorized body) over the application of regulations of labour legislation or the establishment or modification of working conditions, which are resolved in the manner prescribed by law (Bushchenko, Sliusar, Shvets, 2013). V. V. Lazor argues that a labour dispute is a claim to rights of one part to a labour relation to rights implementation provided for by labour law, collective agreements, other labour contracts, decided by the jurisdiction authority in the manner prescribed by law (Lazor, 2005). O. O. Kondratiev argues that the labour dispute is unsettled disagreements, submitted to the appropriate competent authorities for examination, between the subjects of labour and other closely related legal relations over the application of working conditions, established by law, or other legal regulations, or over the establishment of new (changing existing) working conditions of employees and public servants, not enshrined in normative acts and solved in the manner prescribed by law (Kondratev, 1985).
Therefore, labour disputes are disagreements between an employee and an employer, arising in the course of work, the resolution of which requires the involvement of a third party (in this case, the mediator). To sum up, mediation is primarily a process of peaceful settlement of disagreements that may arise between an employee and an employer. Such activity is carried out, in accordance with the law, by the third impartial party (mediators), which has special knowledge, skills, and abilities. The main purpose of the mediator is to establish a dialogue between the disputing parties and ensure its resolution promptly and effectively on mutually beneficial terms for the disputing parties. Therefore, the benefits of the mediation are: 1) it is the most civilian way of dispute resolution, through which the parties can find an understanding and, possibly, continue to work together, that is, in this case, the ability to meet the needs of both disputing parties increases; 2) it allows to reduce significantly the burden on the courts and reduce court costs; 3 ) it is a more efficient way of labour dispute resolution; 4) according to the world practice, dispute resolution through mediation leads to $98 \%$ of successful implementation of agreements the parties themselves; 5 ) it contributes to raising the level oflegal consciousness of the population and the people's confidence in justice.

However, despite the advantages, the mediation institution in Ukraine, including labour dispute resolution, remains poorly developed, and its implementation is hampered constantly, all attempts to "legitimize" it remain at the level of draft laws. However, global practice shows that mediation implementation is important since $85 \%$ of disputes with a mediator are successful. Therefore, the study of foreign experience in this area is important for the Ukrainian legislator. Considering the positive foreign experience of mediation introduction, the United States of America (hereinafter referred to as the US) should be mentioned first, since for many years this country has demonstrated the effective functioning of the institution under consideration.

The entire US law system is aimed at ensuring voluntarily dispute resolution out-of-court; moreover, the judge may interrupt litigation and advise the parties to work with the mediator. In the US, pilot mediation programs engaging volunteer mediators began in the early 1970s in several large cities. They were so successful that hundreds of other programs were conducted throughout the country over the next two decades, and today the practice of mediation is widespread in the US. The US litigation system is aimed at voluntarily dispute resolution before a court session in most cases; moreover, the judge may interrupt litigation and advise the parties to work with the mediator (Stanovlennia mediatsii v Ukraini). The American Arbitration Association, which has adopted its Rules of Arbitration and Mediation used by internal arbitration as well, is very influential (Podoliak, 2012). 
The US legal framework for mediation is the Uniform Mediation Act of 2001 and local acts, such as Mediation Rules from the United States District Court for the Western District of Michigan. This legal act has united 2.5 thousand different laws regulating mediation in different states. He provides for the basic concepts and terms of the procedure for mediation (Kratiuk, Chernyshov, 2013). It should also be noted that the Act has established legally that mediation has become an integral and growing part of dispute resolution processes in public institutions, dispute resolution programs in communities, commercial and business entities, as well as among private disputing parties. Therefore, in the US, in comparison with Ukraine, the institution of mediation is already an integral part of the legal system of the state. However, it should be emphasized that, in contrast to our country, in the US, the institution of mediation is already well-established and functions effectively.

In the UK, the mediation procedure was established by prominent John Harding (a project in Coventry) and a founder member of the Consortium for Restorative Justice Martin Wright (a project in Wolverhampton). In 1981, the National Victim Support published the First Survey of British Mediation Development, and in 1984, a new public organization, the FIRM, was created, recently renamed to Mediation U.K., which coordinated the regional practice of mediation (Golovko, 1998; Nestor, 2014). In addition, initiatives for mediation are implemented by public organizations such as the National Consortium for the Support and Resocialization of Offenders, Face to Face (York city). Their activities have attracted attention from the Ministry of the Interior, which began to provide organizational and financial support to relevant projects. These projects are financed from local budgets, as well as charitable organizations (for example, the Joseph Rowntree Charitable Foundation) (Golovko, 1998; Nestor, 2014).

In France, mediation services are provided by public organizations, and mediators shall be accredited by the public prosecutor, after which they can sign a contract with the Ministry of Justice of France on the provision of mediation services. They are free for process participants and paid from the state budget (Shynkar, 2016). In Austria, mediation services are provided by the Department of the Ministry of Justice and the Association of Probation and Social Work. The Association is an independent private entity subsidized by the Ministry of Justice and has its own management and quality control system for providing services. In Austria, mediators should have qualifications in the field of law, social work or psychology and undergo compulsory training in mediation programs (Shynkar, 2016).

Undeniably, in Germany, the mediation was "imported" from the US. In this country, the practice of commercial mediation has not yet been widespread, but it has succeeded in forming a professional community of mediators and experts, who practice in the field of alternative dispute resolution, in addition, nowadays the theme of mediation is relevant and is under constant discussion in a wide range of circles. In Germany, along with extra-judicial mediation, judicial mediation gains in popularity, because it is harmoniously integrated into the justice system. Since 2004, judicial mediation has been successfully developing in the form of model projects implemented under the control of German justice authorities in courts of a number of lands of the country (Mediatsiia v mire; Gafner, 2015).

Another European country under consideration is Belgium. The Belgian Law "On Mediation” as of June 22, 2005, defines mediation as a process that allows people, involved in a conflict, by their voluntary consent, to participate actively in solving problems arising from the crime through the help of an impartial third person in full confidentiality; the law emphasizes the confidentiality of the procedure. With intent, the Belgian government speaks of the mediation process, not the procedure. The Belgian law was adopted under the influence of the Council of Europe Recommendations on mediation in criminal matters and the Fundamental Decision of the Council of Ministers of the European Union, and many provisions of these legal regulations automatically transferred into legislative provisions. This concerns the principles of mediation such as voluntariness, confidentiality, immediacy, mediator neutrality, and mediation availability, its admissibility at all stages of the criminal process and autonomy within the framework of criminal justice (Sosiura, 2014). In Belgium, almost all mediators are professionals and shall meet high professional requirements. All mediators shall have education in social work no less than at the college level. Personal qualities are also important for the profession of the mediator, such as the ability to work independently, knowledge of the law. In order to engage in mediation activities, each applicant submits a written test and is interviewed. The mediator should not only carry out mediation but also continuously inform and cooperate with judicial and law enforcement agencies to stimulate the transfer of their cases to mediation (Sosiura, 2014).

It is worth noting that mediation is an extremely important component of the legal system of Poland. The first attempt to introduce mediation into Polish legislation was due to the adoption of the new Penal Code, which entered into force on September 1, 1998. In fact, one year was given to train practitioners to apply new criminal law. However, even after the consolidation of mediation in legislation, practitioners' views concerning its application differed due to the lack of clarity of legislative provisions, in particular, who should propose mediation and determine the timing of its conduct (Zemlianska, 2004; Podkovenko, 2016). Much attention is paid to the training of mediators in Poland. The Polish Center for Mediation, established 
in 2000, has a major role in coordinating the mediation and training activities of specialists required, although the history of this association dates back to 1992 . At present, the Polish Center for Mediation has more than 1000 members and more than 50 branches and subdivisions throughout the country and is engaged in mediation in all spheres of public life (including family, educational, civil, economic, labour, social, criminal law, cases on juvenile offenders, collective disputes) with the consent of the courts, the prosecutor's office, the police, individuals, companies, and other institutions. The Polish Center for Mediation actively promotes mediation in Poland as an alternative conflict and dispute resolution (Podkovenko, 2016).

In Ukraine, mediation institution is hampered. For example, in 2011, nearly eight draft laws on mediation were adopted in Ukraine (No. 8137 as of February 21, 2011; No. 10301 as of April 5, 2012; No. 103011 as of April 19, 2012; No. 2425a as of June 26, 2013; No. 2425a-1 as of July 3, 2013; No. 2480 as of March 19, 2015; No. 2480-1 as of April 9, 2015; No. 36651 as of December 29, 2015). Each of these draft laws contained a number of interesting but controversial moments, never implemented. Comparison of Ukrainian draft laws with already existing legislation of other countries shows that both domestic and foreign legislators focus on the issue of admission to the profession of a mediator. For example, the last draft law of Ukraine "On Mediation" stipulates that a mediator may be a person having attained the age of twentyfive, had higher or vocational education and passed professional mediation training, which must include 90 academic hours of initial education, including at least 45 academic hours of practical skills training (Pro mediatsiiu). Similar provisions are in the laws of other countries, in particular:

- in Austria, a professional mediator may be a person who has reached the age of 28 years, has a statutory professional qualification, is credible and has entered into an insurance contract for civil liability (Karmaza, 2017); - in Albania, a mediator may be a person who has a university degree diploma, has reached the age of
25 years, has completed a course of training, has a license, is registered in the register of mediators and has no conviction for committing an intentional crime (Karmaza, 2017);

- in Kazakhstan, a professional mediator is required to have a higher education, to reach 25 , to complete professional training, to be included in the register of professional mediators; an unprofessional mediator may be a person who has reached the age of 40 and whose data is registered as a nonprofessional mediator (Karmaza, 2017).

\section{Conclusion}

Therefore, it should be noted that in Ukraine, in comparison with other countries of Europe and the world, the key problem of mediation institution is the indecisiveness and inconsistency of the actions of the domestic legislator. While most countries improve the appropriate legislation on mediation constantly and effectively, as well as develop new methods, etc.; in Ukraine, the legislator has hardly progressed, avoiding decisive steps. Therefore, the problems of mediation institution in Ukraine reveal the controversial attitude of the Ukrainian authorities towards this institution. On the one hand, the country develops draft laws in this area constantly, and scientists are interested in this issue. On the other hand, the indecisiveness of the legislator concerning the adoption of the Law of Ukraine "On Mediation" is vague since only the adoption of the law will enable to identify practical problems in this area and to determine the vector of further actions. The impression is that, in this way, the authorities are afraid of losing control of society, which could solve a large number of problematic issues without state interference, which in turn results in the loss of funds for corruption by state authorities. However, today Ukrainian society is ready to implement this institution because mediation is an alternative dispute resolution, which enables to solve a number of social and economic problems.

\section{References:}

Materialy kursu pidhotovky mediatoriv iz kola posadovtsiv, yaki zaimaiut kerivni posady v orhanakh vykonavchoi, zakonodavchoi ta sudovoi vlady [Proceedings from the course of training mediators from officials who hold senior positions in the executive, legislative and judicial authorities]. (2010). Spilna prohrama Yevropeiskoi Komisii ta Rady Yevropy «Prozorist ta efektyvnist sudovoi systemy Ukrainy». K. (in Ukrainian)

Hordiienko, R. L. Mediatsiia ta ii rol u konsaltynhovii diialnosti v sferi okhorony zdorovia [Mediation and its role in health care consulting]. Retrieved from: http://nbuv.gov.ua/UJRN/Chkup_2015_3_49

Rau, A. S., Sherman, E. F., Peppet, S. R. (2002). Processes of dispute resolution: the role of lawyers (3d ed.). New York. Polishchuk, M. Ya. (2014). Poniattia mediatsii yak alternatyvnoho metodu vyrishennia sporiv [Concept of mediation as alternative dispute resolution method]. Derzhava i pravo. Yurydychni i politychni nauky, 65, $134-139$. (in Ukrainian)

Moore, Ch. W. (2003). The mediation process. Practical strategies for resolving conflicts (3d ed.). San Francisco.

Yeromenko, H. Mediatsiia yak sposib vyrishennia superechok [Mediation as a way of resolving disputes]. Retrieved from: http://innovations.com.ua/uk/interview/6/39/374 (in Ukrainian) 
Prybutko, P. S., Mykhailenko, R. V., Dubchak, L. M. et al. (2010). Konfliktolohiia: navchalnyi posibnyk [Conflict study: a teaching manual]. K.: KNT. (in Ukrainian)

Shynkar, T. I. (2017). Zastosuvannia mediatsii v administratyvnomu sudochynstvi: vitchyznianyi ta zarubizhnyi dosvid [Application of mediation in administrative legal proceedings: Domestic and foreign experience]. Dissertation for the degree of Candidate of Juridical Sciences (Ph.D.) in speciality 12.00.07. Kyiv. (in Ukrainian)

Guskova, A. P., Matkina, D. V. (2009). Mediatsiia v ugolovnom protsesse [Mediation in the criminal procedure]. Rossiiskii sudia, 2, 10-18. (in Russian)

Demchenko, S. F. (2009). Mediatsiia ta doderzhannia publichnoho poriadku yak skladovi funktsionuvannia modelnykh hospodarskykh sudiv [Mediation and observance of public order as components of functioning of model economic courts]. Visnyk hospodarskoho sudochynstva, 5, 48. (in Ukrainian)

Kuzmina, M. N. (2008). Yuridicheskii konflikt: teoriia i praktika razresheniia [Legal conflict: theory and practice of resolution]. M.: Yurlitinform, 2008. (in Russian)

Ortynskyi, V. L. Hryshchuk, V. K., Matska, M. A. (Eds.). (2008). Osnovy derzhavy i prava Ukrainy: pidruchnyk [Fundamentals of the state and law of Ukraine: textbook]. K.: Znannia. (in Ukrainian)

Bushchenko, P. A., Sliusar, A. M., Shvets, N. M. (2013). Trudovi spory ta poriadok ikh rozhliadu: Navchalnyi posibnyk [Labour disputes and the procedure for their consideration: A teaching manual]. V. V. Zhernakov (Ed.). Kharkiv. (in Ukrainian)

Lazor, V. V. (2005). Problemy pravovoho rehuliuvannia trudovykh sporiv i konfliktiv za umov formuvannia rynkovykh vidnosyn $\mathrm{v}$ Ukraini. [Problems of legal regulation of labour disputes and conflicts in under formation of market relations in Ukraine]. Dissertation Abstract of $\mathrm{PhD}$ in Law. Kyiv. (in Ukrainian)

Kondratev, A. A. (1985). Garantii okhrany trudovykh prav rabochikh i sluzhashchikh [Guarantees of labour rights protection of workers and employees]. Dissertation Abstract of PhD in Law, 12.00.05. Moscow. (in Russian)

Stanovlennia mediatsii v Ukraini: yak znakhodyty kompromis bez sudu [The emergence of mediation in Ukraine: how to find a compromise out-of-court]. Retrieved from: http://ukrainepravo.com/news/ukraine/stanovlennyamed-ats-v-ukra-n-yak-znakhoditi-komprom-s-bez-sudu/ (in Ukrainian)

Podoliak, S. A. (2012). Mediatsiia yak alternatyvnyi sposib vyrishennia konfliktiv u sferi hospodariuvannia [Mediation as alternative method for solving conflicts in economy]. Sudova apeliatsiia, 2, 134-139. (in Ukrainian)

Kratiuk, D. A., Chernyshov, V. V. (2013). Protsedura mediatsii v SShA. Sravnitelno pravovoi analiz federalnykh normativno pravovykh aktov SShA i RF [Comparative legal analysis of federal regulatory legal acts of the United States and the Russian Federation]. Retrieved from: http:9/xn--h1aoo0b.xn--p1ai/1-2013/8.pdf (in Russian)

Golovko, L. V. (1998). Alternativy ugolovnomu presledovaniiu v sovremennom angliiskom prave [Alternatives to criminal prosecution in modern English law]. Pravovedenie, 3, 103-112. (in Russian)

Nestor, N. V. (2014). Mediatsiia u kryminalnomu protsesi Spoluchenoho Korolivstva Velykoi Brytanii [Mediation in the criminal process of the United Kingdom of Great Britain]. Biuleten Ministerstva yustytsii Ukrainy, 12, 144-148. (in Ukrainian)

Shynkar, T. I. (2016). Zarubizhnyi dosvid pravovoho zabezpechennia mediatsii ta mozhlyvist yoho vykorystannia $\mathrm{v}$ Ukraini [Foreign experience of legal provision of mediation and the possibility of its practice in Ukraine]. Nashe pravo, 2, 54-58. (in Ukrainian)

Mediatsiia v mire [Mediation in the world]. Retrieved from: http://mediation.co.ua/2012/09/mediaciya-v-mire (in Russian)

Gafner, K. E. (2015). Razvitie mediatsii kak kommunikativnoi praktiki i ee institutsializatsiia [The development of mediation as a communicative practice and its institutionalization]. Proceedings from XVIII International Conference Commemorated to Prof. L. N. Kogan on Culture, Personality, Society in the Modern World: Methodology, Experience of Empirical Research, March 19-20. Ekaterinburg: [UrFU]. (in Russian)

Sosiura, O. O. (2014). Mediatsiia yak alternatyvnyi sposib vyrishennia sporiv [Mediation as alternative dispute resolution]. Chasopys Akademii advokatury Ukrainy, 4(25), 59-65. (in Ukrainian)

Zemlianska, V. (2004). Vyvchennia dosvidu Polshchi u sferi mediatsii [Study of Poland's experience in the field of mediation]. Pravo Ukrainy, 3, 135-137. (in Ukrainian)

Podkovenko, T. O. (2016). Instytut mediatsii: zarubizhnyi dosvid ta ukrainski perspektyvy [Mediation institute: foreign experience and Ukrainian perspectives]. Aktualni problemy pravoznavstva, 1, 26-31. (in Ukrainian)

Pro mediatsiiu [On mediation]. Draft Law Ukraine no. 3665-1 of December 29, 2015. Retrieved from: http://w1.c1.rada.gov.ua/pls/zweb2/webproc34?id=\&pf3511=57620\&pf35401=371748 (in Ukrainian)

Karmaza, O. (2017). Instytut mediatsii: osnovni kontseptsii rozvytku [Institute of mediation: basic concepts of development]. Pidpryiemnytstvo, hospodarstvo i parvo, 2, 24-28. (in Ukrainian) 